\title{
LeITURA DE NiETZSChE: ZARATUSTRA
}

\author{
[READING OF NiETZSChE: ZARATUSTRA]
}

\begin{abstract}
Resumo: O texto deste artigo é resultante de leitura da obra de Nietzsche Assim falava Zaratustra. Consiste em argumentos sobre o teor de filosófico presente nos discursos poéticos que compõem a obra referida. Buscase mostrar como o conteúdo de poético, a partir do qual Nietzsche estabelece o conceito "Zaratustra", está a indicar isso. De outra parte procura-se fazer compreender que a condição de poético por si só não é o que define o filosófico que os discursos poéticos exprimem; ela pode até levar a se duvidar que o conteúdo de filosófico possa ser identificado ou encontrado em qualquer que seja o tipo de poesia. Esse paradoxo manifesta o desafio de se ter de encontrar o saber filosófico para além do que é dado e efetivado.
\end{abstract}

Palavras-chave: Saber filosófico. Zaratustra. Nietzsche.
Miguel Antonio do Nascimento * Universidade Federal da Paraíba, Brasil
ABSTRACT: The text of this article is the result of reading the work of Nietzsche Assim falava Zarathustra. It consists of arguments about the philosophical content present in the poetic discourses that compose the referred work. It seeks to show how the poetic content from which Nietzsche establishes the concept "Zarathustra" is indicating this. On the other hand, we try to make it understand that the condition of poetic in itself is not what defines the philosophical that poetic discourses express. It may even lead to doubt that philosophical content can be identified or found in any kind of poetry. This paradox manifests the challenge of having to find philosophical knowledge beyond what is given and accomplished.

KEYwORDS: Philosophical knowledge; Zarathustra; Nietzsche.

1. A obra de Nietzsche, Assim falava Zaratustra, é um texto de cunho poético. Não vamos encontrar nele, propriamente, a descrição do elemento filosófico da concepção do pensador Nietzsche. Também não corresponde ao formato exigido pela objetividade, na concepção de científico, para ser a base da argumentação filosófica. Desse modo, por si mesma, essa obra chama a atenção para outro modo de tratar a natureza do conhecimento filosófico.

Convém, pois fazer a pergunta: o que se pode identificar de filosófico na concepção filosófica de Zaratustra? Na pergunta está pressuposto que, quem interroga já tenha em vista uma concepção de saber filosófico, em relação à qual a concepção de Zaratustra resultasse equiparada. Vê-se, então, que há subentendida na pergunta a necessidade de que o significado de "filosófico" venha a ser comparado com o já concebido e, ao final, explicado e compreendido. Mas, depois disso, ainda há outra dificuldade que se pode tomar como um defeito: é que aparentemente há nesta pergunta

* Professor aposentado do Departamento de Filosofia da Universidade Federal da Paraíba. Email:miguelantonio@gmail.com 
algo de redundância, pois se se diz que a concepção é filosófica, não faz sentido ainda querer saber em que consiste o filosófico dela. Assim, esta provocação inicial com a pergunta redundante quer apontar para o outro modo referido de lidar com a filosofia.

O objetivo é dizer que, apesar de não parecer, o poético aqui revela implicação estrita com o conteúdo de filosofia. Para esclarecimento disso convém destacar Zaratustra dizer que "os poetas mentem demais". Procura até mesmo ser visto afastado deles, quando se expressa nestes termos: "Cansei-me dos poetas, antigos e novos: superficiais são todos eles para mim, e mares sem profundidade"(NIETZSCHE, KSA 4, p. 165) ${ }^{1}$ Pode parecer nesta afirmação, que Zaratustra está a condenar o ser poeta. Mas, bem entendido, a afirmação não diz que ele está de forma alguma cansado de algum poeta e sim de quando eles fazem a poesia não conseguir chegar até a devida profundidade do conteúdo de que ela pode tratar. $\mathrm{O}$ elemento da profundidade na poesia precisa ser, portanto, o mesmo que Zaratustra está a considerar na filosofia; melhor: o assunto em questão não trata do que diz a poesia e sim do que diz a filosofia. É isso, pois, o que tem de ser levado em conta por nós. Notemos com atenção especial a passagem em que Zaratustra se exprime pressionando-se a ser cobrado para se explicar por que razão ele chama os poetas de mentirosos, mas sem negar que ele próprio é poeta também. Assim, ele não se ocupa de impedir que prevaleça aí o dizer poético. Antes o deixa valer por si, ao se exprimir nestes termos: "Nós [poetas] sabemos pouco demais e não somos bons aprendizes; logo, temos de mentir" (KSA 4, p. 164).

Não se pense que Zaratustra, com isso, quer ser compreendido dentro da lógica de uma proposição considerada verdadeira. Ou seja, aqui, precisar mentir não quer dizer mentira - quer expressar um jeito de se alcançar verdade em filosofia de forma inescapável; poetas e maus aprendizes, isso não quer dizer nem uma coisa nem outra nem fazer poemas ruins nem ter dificuldade de aprender ou ser ensinado; em vez disso, isso quer dizer, paradoxalmente, ter de ser um filósofo capaz de pensar de modo mais filosófico. No caso, qual é o conteúdo de filosófico que está aí em questão?

A provocação relativa à mentira insta o raciocínio a expor a própria mentira. Ela está subentendida no que diz Zaratustra, portanto resulta percebida e compreendida por ele. Está no contexto como a condição em que o poeta se reconhece nela, inevitavelmente. É por isso que ele precisa vir a mentir. A condição revela que aí a realidade é falsificada e que ninguém está fora dela, incluindo todo poeta. Significa dizer, sobretudo, que isso é assim porque tinha de ser compreendido como mentira, mas tem sido compreendido como verdade. É esta a real razão que leva o poeta a mentir, mas ainda assim é imprescindível entender que, no poeta, o poder mentir é aí ambivalente; uma das valências é afirmativa porque é eco da verdade; é perseguida assim como um viés da mentira enquanto é comum com o saber filosófico, por causa da verdade. A crítica de Zaratustra aos poetas não é, pois ao conteúdo de poético, nem à poesia nem a poeta algum, mas à filosofia. Neste sentido, Zaratustra diz em linguagem poética o seguinte: "Eu sou de hoje e de outrora", "mas algo é em mim que é de amanhã, de depois de amanhã e de algum dia" (KSA 4, p. 165).

Digamos que se chega a entender o que Nietzsche, nesta afirmação, critica na filosofia do passado e na filosofia de seu tempo. Mas o mesmo não ocorre com o que fica indicado só em metáfora, a saber: aquele "algo que é de amanhã, de depois de amanhã e de algum dia". Para acompanhar o que isso quer dizer, dependemos de interpretação do elemento enigmático e metafórico aí subjacente. Até mesmo o que já é definido por Nietzsche como filosófico e parecendo claro, a rigor não se deixa alcançar e reconhecer, senão a partir do metafórico. O conteúdo de metafórico está a revelar que não é diferente um do outro o amanhã, o depois de amanhã e o de algum dia. Consequentemente irá incluir por fim o próprio "hoje" e o "outrora" também, mesmo 
que isso não apareça igualmente anunciado. É que não é o tempo que causa esta separação, conforme diz Zaratustra em outro momento: "nenhum tempo há na terra" para determinadas coisas (NIETZSCHE, 1938, p. 327). Não é enfim um tempo diferente do outro e sim o mesmo, embora não enquanto um em si no presente, no passado, no amanhã e no que é alguma vez; revela-se, antes, só como poder não virar isso - não virar este mesmo em si que, não podendo deixar de ser só um ideal disso, continuasse sendo, porém, como se fosse algo já dado e efetivado, para a realidade toda se fazer representar - e assim passar a existir como uma mentira.

2. O que foi dito até aqui contempla o que segue como tentativa de explicação daquilo que está em jogo para ser priorizado no tema em curso. Mas, isso não se dá a compreender diretamente e sem dificuldades. Convém por isso destacar antes duas afirmações de Nietzsche sobre sua obra Assim falava Zaratustra. Ele diz que (1) é preciso ter muita atenção para se conseguir "ouvir corretamente o som que vem desta boca", a boca de Zaratustra; é que (2) se poderia cometer "lamentável injustiça" para com o conteúdo de sua "sabedoria" (KSA 6, p. 259). A palavra "som" aqui - como tudo o mais relativo a Zaratustra - tem sentido figurado e indica que se deve evitar o engano que seria tomar-se uma coisa por outra no processo de compreensão desse suposto conhecimento: estaríamos na condição de não compreender a verdade desse saber em questão aí. Será, então, que se deveria concluir que se trata de um conhecimento proveniente da genialidade de alguém talentoso e pertencente somente a ele, então Zaratustra? Um saber particular, exclusivo de alguém e não de cunho universalizável? Não é o caso. Este saber em jogo não se restringe à particularidade de quem é genial. Deve-se poder perceber isso, antes mesmo de se ver descrito o alegado equívoco possível de ser cometido contra ele: cada capítulo dessa obra - e, mesmo e sobretudo o prólogo - possui a estrutura de começo, meio e fim, exprimindo pois que está em jogo aí o poder de universalizar a multiplicidade das coisas em mundo e realidade. Por conseguinte não aponta para um saber em particular. Não se justifica como um conhecimento especial, que fosse também de alguém especial, dotado de uma inteligência sui generis e poderes especiais. Ao contrário, o mais autêntico modo de ver, próprio a Zaratustra identifica-se com o que há de antigo e - no sentido de que está no todo do pensar nietzschiano e desde seu início - é também um pretensioso propósito de atingir o âmago e a abrangência de tudo o que vem a ser universalizado: desde a obra $O$ nascimento da tragédia encontra-se o "acontecimento Zaratustra" já gestado nisso; aí já "se ouve o acento histórico-universal" no sentido de que "soam tons históricouniversais neste escrito" (KSA 6, p. 314). Nesse sentido trata-se do saber que instituiu a história da filosofia. Assim, com as duas afirmações referidas acima, Zaratustra está sendo considerado, por Nietzsche, um sábio - mais exatamente, o mestre da "doutrina do "eterno retorno" - e como se pode deduzir, ele é considerado assim, em razão do conteúdo que tradicionalmente implica o sentido histórico-filosófico disso. De outra parte, apesar disso permanece existente e insistentemente a dificuldade peculiar para se compreender o pensamento de Zaratustra. Daí a justificativa de precaução face à possibilidade de equívoco e "injustiça" quando se vai concebê-lo. Significa que esta dificuldade reside na própria concepção da verdade desse saber, que diverge muito entre o como Zaratustra o concebe e o como os demais filósofos e sábios o concebem. Em conseqüência ocorre de ele se afastar de antemão de seus lisonjeadores apologistas e seguidores, mas também de opositores e críticos que não chegam a compreender o conteúdo do saber em questão. Há então, já de partida, certa indiferença e desinteresse de Zaratustra em ser ou não compreendido. Neste contexto é que a obra Assim falava Zaratustra se dispõe como um texto de cunho poético e não do tipo padrão de texto de filosofia - de cunho sistemático e argumentativo. 
É, pois, em razão do próprio conteúdo fỉlosófico fundamental que fala Zaratustra e, é ao mesmo tempo nisso também que se poderia cometer um erro ao se tratar desse texto, embora supondo que estivesse, porém, de acordo com seu autor: qualquer um pode falseá-lo ao tomá-lo justamente pelo que considera nele mais plausível e "verdadeiro"; ao tomá-lo como elevado ensinamento de um grande mestre, por ser direcionado ao vivente homem para conduta em seu percurso de vida entre o nascimento e a morte. Seria isso ainda assim "lamentável injustiça", pois o que vale por verdade naquele "conteúdo" não se reduz à realidade efetivada em sua condição de dado, a ponto de um mestre - mesmo se for o maior de todos e até divino - poder tomála por verdadeira, e possível de ser aplicável na condução da vida de quem quer que seja que lhe hipoteque fidelidade. Em vez disso, o teor de filosófico desse "conteúdo" reside é no a mais do todo dado-efetivado como realidade. O "a mais" quer dizer aquilo que extrapola a condição de efetividade consumada. Assim, se nos encontramos mecanicamente condicionados a isso, estamos fadados a conceber a verdade de modo equivocado. Por isso, quando é atribuída a Zaratustra a condição de "mestre do eterno retorno", não quer dizer, pois, que ele conhece a verdade de um saber extraordinário, então possível de ser ensinado, ainda que como conhecimento novo. Em consonância com esse fato percebemos Zaratustra se exprimir deste modo: "Ser verdadeiro - isso poucos podem. E, quem o pode, este não o quer ainda! Menos que todos, porém, podem-no os bons" (KSA 4, p. 251). Aí não se trata, acima de tudo, de ser fiel à verdade, mas de se dispor a compreendê-la.

Tudo nesta declaração, porém, tem sentido figurado, de forma que ela não está a dizer nem que a verdade como tal se encontra dada nem que se possa ser desobediente a ela. Se considerarmos isso, passa a ser adequado juntar à reflexão sobre o conteúdo em jogo, Zaratustra combater a falsa fidelidade à sua condição de mestre e doutrinador. É que a compreensão da verdade do saber que ele ensina não provém de seu poder ensinar, mas do poder compreender, que é próprio só de quem desejar muito isso - sob modo de disposição. Assim, Zaratustra critica não só os que são considerados 'sábios' justamente no que conseguem ser indiferentes a isso; mas também os que se consideram do seu lado e até se tomam por seus seguidores devotos, mas ainda assim ele os adverte e lhes fala, então, como que a bajuladores, nestes termos: "Por que não quereis arrancar louros de minha coroa?" (KSA 4, p. 101). Quer mostrar que, quem lisonjeia a quem venera como um pretendente, este se impede de compreender a si mesmo; impede-se de perceber aquilo que só se deixa ocorrer como confirmação do que já sempre é naquele que o busca. Iria acabar sendo apanhado de surpresa, sem o tempo de se arrepender e mudar - semelhante à metáfora em que alguém pode acabar sendo esmagado pela "estátua" do próprio ídolo que ele carrega. Procura então alertá-los quanto à falsificação da verdade em seu próprio âmago; procura, para isso, desconsertá-los e tocar-lhes bem no íntimo, dizendo: "Ainda não havíeis vos procurado a vós mesmos: então me achastes. (...) Agora, eu vos mando perder-vos e achar-vos a vós mesmos" (NIETZSCHE, 1983, p. 92)

3. Retomo a pergunta feita antes sobre o conteúdo filosófico que está em questão. O conteúdo de filosófico sistematizado pela história da filosofia é tomado por Nietzsche como sendo moral e metafísico. Nessa condição cumpre uma função: poder determinar desvio da linguagem própria à constituição incondicional da vida, deixandoa esvaziada da destinação de ser o conteúdo de "algo que é de amanhã, de depois de amanhã e de algum dia”. O caráter enigmático e metafórico nestas palavras de Zaratustra estabelece a ligação, mediante a qual Nietzsche projeta o novo conteúdo que teríamos de apreender em detrimento do outro, moral e metafísico, a ser superado. Isso não se daria sem que atingíssemos com a compreensão o fato de que é a vida a origem 
do conteúdo novo que a filosofia teria de exprimir. Ao associar isto com o conteúdo de metáfora, de enigma e de Zaratustra, Nietzsche torna mais nítida a diferença para com a forma como a concepção de vida resulta negativa e falseada pela constituição moralmetafísica. Neste contexto, Zaratustra e o respectivo dizer poético passam a ser a forma mais radical empregada por Nietzsche para tratar do conteúdo da filosofia.

Nova forma de tratar do problema fundamental e antigo do conhecimento do mundo e das coisas, isto é o que coexiste com a explicação do significado de Zaratustra, dada por Nietzsche. No caso aqui, Zaratustra critica o que foi feito historicamente deste saber e o que ele é ou precisa ser. Ele teria sido o primeiro que "viu na luta do bem e do mal a verdadeira roda motriz na engrenagem das coisas..." (KSA 6, p. 367). Fora dado a bem e mal a consistência de moral e metafísico, enquanto suficiência de se poder diferenciar respectivamente entre permanente-imutável e efêmero-variável para se fixar como princípios metafísicos, "causa", "fim em si", "força", etc, e, com base neles e no caso de conseguir, considerar as coisas como verdadeiras. Agora seria preciso acusar isso de ser um equívoco e superá-lo; seria essa tarefa obra de Zaratustra.

Mas também cuida Nietzsche, sobretudo, de apresentar Zaratustra aí como a superação da moral, para ser isso oposição fundamental ao construto moral-metafísica. Significa que não se trata de uma oposição com valor meramente de substituição. Zaratustra passa a ser no homem a condição de ele não ter como nem por que substituir alguma coisa por outra na existência nem muito menos precisar remover ou extinguir alguma coisa em relação a si próprio. Nada se extingue no âmbito da existência nem chegam ao fim a moral e a metafísica; o fim é só da dualidade moral-metafísica da concepção de bem e mal; é desaparecimento de um "erro" de percepção de determinada coisa, se comparável à relação entre ausência de sombra do "meio-dia" (Cf KSA 6, p.367). Isso diz da complexidade da existência, enquanto operação própria à dinâmica da "engrenagem das coisas", a que está também conectada intrinsecamente a compreensão humana de "bem e mal".

Trata-se de algo que está na base da necessidade humana de conhecimento de si em relação às coisas; na base de um saber dizer o que o homem é e que se diferencia de outros entes. É isto o que faz Nietzsche não somente criticar o como se definiu isso até então, como ainda ele próprio se tomar dentro de tal necessidade de tratar do problema, mas permanecer nela, sob o signo de "auto-superação".

Há por trás disso o empenho de Nietzsche de combater o aprisionamento da vida, que cede posição e vigor para o que se efetua como vantagem dada pelo construto moral-metafísica em tudo o que o teor de valor pode permitir. Junto com esse combate vem a dificuldade mais antiga e poderosa que é não se saber como se venceria a falta de sistema garantido historicamente pela metafísica e moral. Em suma está em jogo de que forma se poderia assegurar o essencial do sentido que a vida se possa dar em verdade. $\mathrm{O}$ saber filosófico resultara na metafísica e na moral como experiência e resolução relativamente a isso. Nietzsche critica o desviar-se do fundamental que a vida é como vontade de poder; o desviar-se promovido pela moral e metafísica

Em consonância com isso, a crítica que Nietzsche faz à filosofia de até então se firma em empenho de não permitir que a realidade seja tomada como algo dado e efetivado; em lugar disso mostra-se como aquilo que está sendo feito; como o nosso crer naquilo que se dá no que algo dura e fica nisso de forma regular, conforme nosso modo de viver:

"A vida está fundada na pressuposição de uma crença em algo que dura e que retorna regularmente; quanto mais poderosa é a vida, tanto mais amplo tem de ser o mundo previsível como que sendo feito. Logicização, racionalização, sistematização como meio de auxilio do viver" (KSA 12, p. 385, 9[91]). 
Notemos nesta definição de vida os dois aspectos que interessam: por um lado o aspecto dos meios como a vida se efetiva - ou seja, ela se efetiva através de "racionalização", "logicização", "sistematização", etc; e, de outro lado, o aspecto mais fundamental, o do caráter enigmático e metafórico - a saber, a fé no durável e regular. Notemos em seguida que a força de enigma presente no que está dito é que expressa aí a noção de vida e sob a intenção de Nietzsche, de que isso seja o elemento de que a filosofia teria de tratar, mas não o fez. Portanto trata-se de uma tarefa de filósofo - no caso, tarefa dele, Nietzsche - e na condição de um crítico. Toda a história da filosofia teria mantido um engano ao vincular o significado de vida à busca humana da felicidade, mas sem que isso coincidisse com o que a vida é enquanto crença no poder gerar duração e retorno.

Por causa desse engano, a força de enigma presente no que está dito tem uma mesma chave de se compreender o que é já fornecido por Nietzsche no todo de seu pensamento com o conceito "vontade de poder". Isso deve ser levado em conta se quisermos compreender o que Nietzsche quer que valha por filosófico em filosofia. De um lado isso se dá como mecanismo de crítica ao que a história já estabilizou e conseguiu consagrar por conhecimento filosófico. A partir do conceito vontade de poder, o que se vai alcançar por conteúdo de filosófico na obra Assim falava Zaratustra pretende ir para além do que se identifica pura e simplesmente com conteúdo conferido pela história da filosofia como tal. De outro lado dá-se como mecanismo de não deixar que o conteúdo de filosófico se reduza à condição de simples meio de realização da vida enquanto algo dado e efetivado; e, neste sentido, tomado de antemão - ou seja, de modo metafísico, como 'princípio' e 'verdade'. Em apóio a isso se encontra uma declaração de apontamento de Nietzsche, do início de 1883, em que ele diz não ser a nossa motivação fundamental o ainda buscar viver, como meio de realização da vida. Tal motivação se daria somente como vontade de poder: "Vontade de vida? Encontrei em lugar disso sempre só vontade de poder" (KSA 10, p. 187, 5[1]). No modo de falar assim ganha destaque, automaticamente, a diferenciação entre vontade de viver e vontade de poder. Vontade de viver diz o mesmo que desejar ou querer alguma coisa no caso, querer viver. Já o mesmo não posso aplicar para vontade de poder; vontade de poder quer dizer aqui não ser já nada de efetivo, ao tempo que é poder deixar que se efetive o que quer que possa se efetivar. Trata-se da condição de nada ser e isto mesmo é o poder ser de qualquer coisa que vem a ser. Nesta condição é que vida é concebida como não podendo ser outra coisa senão vontade de poder.

Logo se deixa perceber na afirmação citada algo difícil de entender. Significa dizer que a diferenciação entre vontade de viver e vontade de poder não é direta nem clara. Repito a afirmação mencionada: "Encontrei sempre só vontade de poder", quando buscava a vontade de viver. A diferenciação subjaz na pergunta: Em que é que vontade de poder e não vontade de viver é o que ocorre? "Subjaz", isso quer dizer: o que ocorre, já sucede desde sempre àquilo que o deixa ocorrer. Esta é uma diferenciação não lógica, no sentido de que vida é o poder deixar algo ocorrer e não o segui-lo enquanto o querer para si esse algo; vida é o poder todo de deixar ser o que vem a ser, por isso nunca se reduz a um único querer ser, mesmo que este se suponha coincidir com o próprio viver e com o não querer morrer. Neste sentido nunca pode ser ainda querer alguma coisa como o viver. Por esta outra razão é que ganha primazia e denominação a "vontade de poder".

Depois de se considerar isso implicado à concepção filosófica de Zaratustra, convém deixar preponderar o elemento de enigma e metáfora presente no falar poético e na natureza da vontade de poder como vida e não só como conceito. Nesta compreensão é que o discurso poético de Zaratustra guarda a primazia de metafórico e 
de enigma, também enquanto excelência para se assegurar o conteúdo de filosófico na filosofia. Aqui se encontra a resposta adiada, para a pergunta feita acima: "Qual é o conteúdo de filosófico que está em questão no poético?" A primazia no metafórico quer dizer o elemento para gênese dos conceitos próprios à linguagem filosófica. É preciso explicar isso com indicação do próprio Nietzsche sobre o que significa sua tarefa como filósofo, que é ser obediente ao que sempre já é enquanto vida: o que ele diz é que enquanto vida, tudo é só vontade de poder - inclusive nós próprios. Mas a expressão "tudo é só vontade de poder" não é para definir vontade de poder como algo único, e no sentido de um princípio; é antes para exprimir que o que quer que exista ocorre já como acréscimo, cumulação, força, - relativamente à vida. A menor efetivação de alguma coisa terá de ocorrer já desde um plus, um quantum de potência enquanto a dita efetivação. Já a vontade de poder nisso é sempre o poder de zero possibilidade de ser algo efetivo ou dado; e não se trata da conotação de nulo ou de neutro e sim de poder enquanto impede de se tornar efetivo e dado, mas também enquanto se deixa falsamente se tornar efetivo e dado. É, pois, poder ser uma coisa e também a outra.

É assim que vontade de poder é tomada por primazia e gênese quando se quer esclarecer o fato aludido acima de que os poetas têm de mentir; de que sabem pouco demais e não são bons aprendizes, visto que o máximo de conhecimento na esfera do que é dado e efetivo não visa à verdade da poesia e da filosofia; visa à "logicização", à "sistematização", à "racionalização" e semelhantes. Enquanto vontade de poder, portanto, enigma e metáfora como mentira constituem a verdade do conteúdo do poético e do filosófico. Neste sentido é também por isso que a explicação do conteúdo de filosófico no filósofo - que é capaz de pensar de modo mais filosófico - quer significar o jeito exclusivo de se alcançar verdade em filosofia.

4. Nietzsche, mesmo no final de sua carreira, ou seja, mesmo quando poderia caso quisesse - rever e mudar alguma de suas convicções, não demonstra precisar disso no que respeita ao essencial de seu pensamento; antes o ratifica e o fortalece com a concepção crítica de que aconteceu de se efetivar como um erro fatal a até então tradição histórico-filosófica ter instituído a compreensão das coisas através de moralização da diferença peculiar entre bem e mal. Nietzsche vem a expor e acusar, com isso, um modo equivocado de se conceber o conteúdo da implicação bem e mal. A partir deste fato, ele indica que seria tarefa primordial o empreendimento de superação desse equívoco; dá a entender que a concepção filosófica que possa compreender este fato precisa coincidir com a característica fundamental de uma atitude à altura desse empreendimento. Corresponde a isso o "acontecimento Zaratustra". O significado de Zaratustra encontra-se vinculado ao mesmo significado da mais profunda convicção de enfrentamento e êxito relativos à referida concepção de erro histórico em que a humanidade se enredara. Nesse contexto temos o termo "Zaratustra", apresentado por Nietzsche, como que correspondente a alguém que é o destruidor de toda e qualquer moral (Cf. KSA 6, p. 367ss.). Uma das formas que diz isso é a expressão o "primeiro imoralista" - que Nietzsche atribui a si próprio e que aparece em Zaratustra como incorporação sua. De modo subjacente, isto se vincula ao conceito Zaratustra como a expressão de uma alta capacidade de pensar - que pensa com profundidade e com argúcia crítica - e que é responsável pela percepção de que na relação bem e mal se encontra estabelecida impropriamente uma "trasladação do elemento moral para o metafísico (die Übersetzung der Moral in's Metaphysische)", percepção esta que deveria ser ultrapassada sob o modo de uma "auto-superação da moral pela veracidade". A amplitude de conteúdo disso, ou seja, poder não só perceber e contestar o caráter falso empreendido por toda a história da filosofia enquanto interpretação da realidade circunscrita à relação de distinção moral entre bem e mal, mais ainda poder 
dizer o como transformá-la, nisso consiste o significado de Zaratustra: "Sua doutrina e só ela tem a verdade (Wahrhaftigkeit) como a mais elevada virtude..." Teríamos de perceber que a conotação de moral só surge no que o homem pode conseguir isso - não é algo por si mesmo. Ela ganha evidencia como uma espécie de função, a rigor desnecessária quando vista e tomada por um poder já intrínseco à ação humana. Nietzsche deixa que se conclua que ela provém da dinâmica com que algo pode diferenciar uma coisa de outra, mas sem poder de uma forma ou de outra deixar de ser algum dia isto que sempre já é enquanto poder respectivo; ou seja, sem poder se reduzir a esta função como tal, correspondente ao que sempre pode ser algo e se encontra aí subjacente - enquanto "vontade de poder". Por extensão, ao se passar a ver também de outro ângulo tudo isso, o que se alcança é tão só o mesmo ponto sob perspectiva outra: o máximo distanciamento crítico da moral faz o compreender atingir seu ponto de chegada como aquele de onde ninguém tem de sair. Em outras palavras, aquela implicação negativa entre erro, moral e o conteúdo de bem e mal quer exprimir um modo equivocado de concebê-la. Ela se põe como a constatação e acusação de indevida "trasladação da moral para o metafísico" e que, agora, o empreendimento de superação deste erro teria de ser a tarefa primordial. Põe-se como uma acusação, por isso evita que se questione se consegue ser um ultrapassar enquanto passar para fora de onde se está, não tendo mais de permanecer onde sempre se esteve. Poder-se-ia, porém, saltar passando para outro âmbito que não fosse ele mesmo como outro? E o que aí poderá ainda querer valer como "primeiro" em algum homem se tomar por "imoralista" Zaratustra?

Para tal coisa, a tarefa implica o desafio de não conformar sua verdade à compreensão fornecida só pela linguagem já existente e corrente. A linguagem enigmática e metafórica em Zaratustra se efetiva como ultrapassagem disso. Assim também, toda a criação de Zaratustra traz em seu bojo nova providência com vistas a essa ultrapassagem relativa à tradição filosófica. Para alguém compreender Zaratustra requer considerar tal peculiaridade. Enquanto "imoralista", Zaratustra não quer ser um sábio moralista a mais dentre outros - nisso então pode ser tido pelo "primeiro": pode ser notado por nós como uma concepção filosófica e não como uma pessoa ou personagem. Aqui, isto precisa significar como conteúdo, a verdade da superação da fixação moral de bem e mal. Quer dizer que, embora isso tenha por foco atingir e ultrapassar esta dualidade enquanto platonismo e cristianismo - essência e aparência, eternidade e mundo - o alvo é mais que isso; é outra coisa para além deste "foco". O alvo é comparado, metaforicamente, ao "meio-dia". Ao meio-dia, a luz do sol não deixa a abundância de sombra predominar e a escuridão desaparece. A oposição entre luz e sombra não encontra chance de se fazer presente. A comparação é feita para se tomar como compreendido e aceito o significado deste começo de Zaratustra: uma dimensão que possa ser ao mesmo tempo indiferença a toda a oposição e dualidade - todo início é aí também todo fim. Em tal indiferença extinguem-se, mas auto-superando-se, 'essência e aparência', bem e mal, 'mundo verdadeiro' e "mundo aparente" (Cf. KSA 6, p. 80-82). Zaratustra se faz compreender, então, como aquilo que é o mesmo ponto de partir e chegar, começar e terminar. Sua origem é igualmente sua destinação e, consequentemente também, natureza de sua existência. Zaratustra significa enfim concepção humana da existência: é "ponto culminante da humanidade".

Esta noção de começo quer ser radicalmente diferente de 'princípio' moral metafísico, que não poderia evitar ser "uma ilusão ótica de ordem moral" (KSA 6, p. 8082). O conteúdo de moral tornado em conteúdo de metafísica diz de um fundamento moral, ou seja, do elemento moralizante que é concebido por fundante - mas indevidamente. Em consonância com isso vale aqui mostrar como inter-relacionadas a 
crítica à moral e a concepção filosófica de Nietzsche. Para ele, já em $O$ nascimento da tragédia, deveríamos identificar "uma prova totalmente inequívoca" de que, com sua subjacente convicção filosófica nunca temeu algum tipo de "risco", que pudesse advir de "qualquer idiossincrasia moral" (KSA 6, p. 78). E é isso assim porque esta convicção não decorreria do conteúdo da 'verdade' e da 'certeza'. Em seu lugar passa a se fortalecer o entendimento de que o viver "quer" e busca ser "engano". Assim nunca podia vir a ser algo 'verdadeiro'; ele não resulta de uma 'certeza' - "não é excogitado pela moral” (KSA 2, p. 14). Nessa convicção encontra resposta a interrogação formulada acima: "qual é o conteúdo de filosófico que está em questão" quando "precisar mentir não quer dizer mentira"?

A obra Assim falava Zaratustra nos induz ao raciocínio de que é preciso compreender, com especial distinção, o significado de "auto-superação da moral". Mas permite, além disso, que se vá até o ponto que é preciso alcançar. Significa que, a rigor, a crítica não é propriamente à moral e à metafísica; é à filosofia, em razão de não se conseguir que ela avance para além disso. Subjaz aí a indagação crítica: o que levara os filósofos à opção pela moralização metafísica do saber filosófico, se possuíam o poder de ir no sentido outro - o da auto-superação como vida? A "especial distinção" para com o entendimento da "superação da moral" concerne a esta decisão pelo sentido que adquire naquilo que gera poder na vontade de poder. Está sendo considerada, por Nietzsche, nesse "poder" a procedência de conteúdo e configuração de vida como superação; isto, e não já a essência do efetivado nisso. Quando se põe no pensar a existência feito um todo - quando se a concebe assim - então, vida resulta pensada como sua (da existência) dinâmica de se dar, compreendida sob conceito de vontade de poder. Sob esta ótica vale aqui retomar referências à vontade de poder feitas acima, no sentido de que é sempre a vontade de poder aquilo que encontramos como base de compreensão da existência: “... sempre só vontade de poder” e na forma de se poder pensar o mundo "como que sendo feito". Onde se encontra a verdade nisso como problema? O alvo fundamental da vida é poder ser mais, como vontade de poder. Enfim, o "específico" nessa "distinção" aponta para a possibilidade de impedir a moralização metafísica de se fazer necessária e imprescindível; isso significa, consequentemente, sua auto-superação. Pode se dizer isso deste modo: ela pode não ser mais considerada necessária: "A moral não é atacada", apenas não é mais levada em consideração...” (KSA 6, p. 330). Seria superação dentro da questão da verdade: uma "auto-superação da moral pela verdade (Wahrhaftigkeit)" (KSA 6, p. 367). Nietzsche quer que possa ser designado "vontade de verdade" - como não verdade - o que considera moral-metafísico. Mas isso quer dizer que quando tem de ser buscado também por Zaratustra, precisa ser a verdade. Isso é o que seria alcançado com a autosuperação da metafísica moral: devolver "o elevado direito e privilégio de existir" (KSA 6, p. 330) ao que não é também considerado o 'bem'.

5. Quando estudamos a criação nietzschiana do "Zaratustra", buscando entender melhor o pensar filosófico de Nietzsche, a linguagem zaratustriana, muito peculiar, pode vir a ser o que mais dificulte isso. Este tipo de dificuldade não deve, porém, ser confundido com outro, que consiste em se tentar atingir o que aí significa conteúdo de saber filosófico; e isso, independentemente de que seja procedente ou não a acusação nietzschiana de que uma base moral e metafísica para o pensar humano é um equívoco na constituição e sistematização que a filosofia empreendeu como história do pensamento do homem. Em relação a esta dificuldade convém repetir que a crítica de Nietzsche não resulta ser à moral e à metafísica propriamente, e sim ao fato de não se ter conseguido ir além delas. Devemos assimilar a compreensão disso, levando em conta duas coisas. A primeira é o que já foi mencionado acima no sentido de que não 
sendo precipuamente intuito eliminar metafísica e moral, então aquilo que as institui permanece constituindo a realidade - enquanto dinâmica da vontade de poder. A segunda é aquilo que, sendo mais que isso e nisso, a linguagem exprime por verdade mas enquanto "a veracidade como a mais elevada virtude" que, como informa Nietzsche, só a doutrina de Zaratustra possui. (KSA 6, p. 367).

Nietzsche emprega o termo veracidade (Wahrhaftigkeit) em vez de verdade (Wahrheit). Dá a entender com isso que precisa garantir diferenciação entre o que já foi compreendido erroneamente pelo significado da verdade; indica a necessidade de criticar o conceito de verdade - criticar o emprego abusivo do conteúdo deste conceito. A concepção da verdade no emprego abusivo - entendido aqui como emprego moralmetafísico - deve levar a se considerar e pensar o distanciamento deste pressuposto equívoco, mas também aquilo que se assegura depois de se afastar dele. Portanto devemos incluir, no dizer de Nietzsche, também o que se encontra só subjacente e subentendido no que é entendido por ele, a saber, a verdade incorporar a "mais elevada virtude". Mas em outros termos, isso pode querer dizer: Corrigido o equivoco, não se poderá desconhecer o conteúdo da verdade então intrínseco ao pensar aí e enquanto questão.

Neste contexto foi destacado acima o fato de Zaratustra advertir seus seguidores quanto ao erro de venerá-lo com base na verdade. Aquele que o segue sob respectiva fidelidade, mantém-se na convicção de que Zaratustra fala a verdade. Mas ter a certeza disso não seria garantia de que a verdade é a verdade. Enquanto questão, uma face da verdade se mostra aí como a exigência mais difícil de ser cumprida, porque a verdade não será encontrada. A outra face da verdade não convém ser confundida com a primeira. Seria aquela tomada sempre e em vão, no que se transforma na não verdade e, consequentemente, permanece confundida com a verdade. É no primeiro caso, pois que precisa valer Zaratustra doutrinar - ensinar sob a admoestação: "Ainda não havíeis vos procurado a vós mesmos: então me achastes. (...) Agora, eu vos mando perder-vos e achar-vos a vós mesmos" (NIETZSCHE, 1983, p. 92)

Interessa a relação entre, de um lado procurar a si próprio, de outro lado nunca achar ou ter achado em outrem aquilo que procura ou procurou. Esta experiência teria de ter aquele que reconhece o que é buscar a verdade. Não é que a verdade seja algo a ser encontrado, mas sim a não se deixar esquecer. O que revela isso não é o que fala Zaratustra, mas mais aquilo por que ele passa, a exemplo da condição de: "ocaso", "convalescente", "dor", etc. - transfigurada em "redenção", "super-homem", "eternidade", etc. Ele consegue, por isso, comportar-se de modo dúplice: decide nutrirse do primeiro caso da verdade, mas priorizar combater criticamente o segundo. Seu tempo o leva a esta opção. Não quer mais correr o perigo de ainda se deixar confundir com a elevação falsificada de verdadeira já criticada por ser metafísica. O resultado é manter a desconfiança junto à necessidade que tem de não perder a fé no homem como em algo firme (Cf. NIETZSCHE, 1983, p. 153). Precisa guardar-se do além-mundo e alcançar, não obstante isso, também a verdade da "mais elevada virtude" que não o negue. Se se pode ver nisso algum desafio, ele se acentua em quem conhece a solução de Platão ${ }^{2}$ - com o conteúdo da verdade no conteúdo da idéia - e quer se distanciar ao máximo disso. Mas, se precisa é fundir verdade e beleza, outro saber para isso ainda se mostra num impasse. Este impasse faz Zaratustra voltar-se para o homem como um prender-se a algo com "solidas corrente", para não se deixar desprender devido a força de algo ainda mais forte, com que não sabe já lidar. Certa vez falou assim: “... é este o meu declive e o meu perigo: que o olhar se me despenhe no alto e a mão deseje segurarse e apoiar-se - no abismo!" (NIETZSCHE, 1983, p. 153). É assim que ele mantém no pudor o conteúdo da instância da verdade. Confessa-se temeroso frente à possibilidade 
de não resistir deixar-se arrebatar por aquela instância "bem aventurada" - "pois é para lá que quer ir minha outra vontade" (NIETZSCHE, 1983, p. 153).

Nessa ambiguidade, Zaratustra não desconhece nem esquece a verdade. Nisso, portanto, é que "Ser verdadeiro - isso poucos podem! E, quem o pode, este não o quer ainda!" (KSA 4, p. 251). Podemos então dizer: Quem "o pode" e "não o quer ainda", sabe que quer a implicação entre uma instancia e a outra; em conseqüência, os "poucos" que podem, é isso também o que devem poder. Aqui se encerra o argumento da admoestação ao seguidor - “(...) Agora, eu vos mando perder-vos e achar-vos a vós mesmos" (NIETZSCHE, 1983, p. 92). Ele teria de compreender isso como o saber mandar: em vez de querer aprender a obedecer a outrem, teria de aprender a querer mandar; mas que entendesse seu mandar como mandar em si mesmo e como perigo; além disso, que fosse tão só obedecer a "tentativa e risco" - que é em que consiste todo o mandar (Cf. KSA 4, p. 147-148); razão de se tornar causa de fuga disso e de refúgio na prostração e obediência escrava a outrem.

Para finalizar convém destacar aquilo, em relação a que se contrapõem os elementos morais-metafísicos da crítica de Nietzsche. Serve aqui sintetizá-los na expressão nietzschiana "vontade de verdade (Wille zur Wahrheit)". "Serve", no sentido de que, já ao pronunciá-la, tem-se aí inteiramente implicado o conceito "vontade de poder (Wille zur Macht)" em sua função ambivalente fundamental de exprimir os dois pólos: tanto o conteúdo criticado como o pretendido e perspectivado por Nietzsche para o pensar humano: querer verdade sempre e, justamente com isso, continuar podendo querer esse querer. $\mathrm{O}$ poder de origem e proveniência da vontade de poder, assim, se dispõe a ser base para refutação e crítica a toda pretensão da verdade como não verdade. Mas nisso dispõe-se antes como poder dar procedência. Neste ponto, o conteúdo da verdade não se desliga do poder e permanece subjacente em conceitos como vontade de poder, eterno retorno, niilismo, etc., Se nisso, Nietzsche prioriza a crítica em vez da analítica da verdade, mesmo assim requer considerar o fato. Enquanto proveniente de sua origem (vontade de poder) e, podendo assumir a condição de ser nisso derivada, a vontade de verdade transforma-se em pretensão de ser a verdade, visto que é, antes de tudo, poder para isto, mesmo não sendo apenas isto em seu poder todo de origem. Com isso, ela se tornou o próprio conteúdo de verdadeiro da verdade em oposição ao de falso; então continuou podendo dar origem também a todo conteúdo e valor para conceitos. Cabe sempre, pois perguntar por que se reduzira à priorização deste único valor moral-metafísico de verdadeiro da verdade. Neste sentido de possuir um conteúdo originário proveniente através da vontade de poder é que o valor de verdadeiro, derivado disso e enquanto vontade de verdade, torna a verdade "não verdade". Zaratustra, então, decide explicar isso tudo assim: Trata-se da "'Vontade de verdade" que, como tal, é uma bem mais primitiva "vontade de que todo o existente seja pensável" (KSA 4, p. 147); jamais iria se reduzir ao verdadeiro da vontade de verdade.

Quando fala assim, Zaratustra se mostra imbuído de contestar até o mais sábio de todos os que se consideram os mais sábios filósofos; ele se mostra totalmente concentrado e absorvido em dissuadir todo aquele que ainda ignora a vontade de verdade, dissuadir da convicção de que a não verdade seja a verdade. Com tal coerência considera que desde sempre o poder ser não verdade detém impropriamente a importância do conteúdo em questão, o da verdade. Combina com isso então repetir aqui o já acima mencionado dizer poético, "Nós [poetas]... temos de mentir". Assim, na expressão "temos de mentir" subiste este entendimento: Não tem porque permanecer no mesmo modo de conhecer e ser, depois de compreender que ele não seria verdadeiro; nem porque querer crescer e ir em direção ao alvo ilusório que é apenas idealizado e 
forjado; que é uma vastidão infinita em vazio de teor da verdade - em vazio de teor daquilo, pois, que sempre somente "pouco demais" podemos saber; alvo algum aí "sabemos" de que modo atingir com acerto. Não há como não sermos, em relação a isso, maus "aprendizes" nem como não preferirmos "mentir".

Isso tudo, porém, diz do que torna possível a "mentira", pois é também o que torna possível a superação dela. Trata-se de um conteúdo fundamental e sempre em questão, atribuído então à vontade de poder, que Zaratustra pode fazer valer como a compreensão daquilo que cria toda a realidade, naquilo que se torna feito, como no que se torna desfeito, no que se constrói, com no que se destrói.

\section{REFERÊNCIAS}

NIETZSCHE, Friedrich W. Assim falou Zaratustra. Trad. Mário da Silva, Rio de Janeiro: Civilização Brasileira, 1983.

NIETZSCHE, Friedrich W. Sämtliche Werke. Kritische Studienausgabe (KSA), volumes 2, 4, 6, 10 e 12. Edição de Giorgio Colli e Mazzino Montinari. Berlin; New York: dtv/ de Gruyter, 1988.

PLATÃO, Fedon. Trad. Jorge Paleikat e João Cruz Costa. São Paulo: Abril Cultural, 1979, 2a ed.

\section{NoTAS}

1 Doravante a palavra NIETZSCHE, na citação, será suprimida e substituída pela sigla $(K S A)$ das obras completas, seguida da numeração de volume correspondente, conforme listagem de REFERENCIAS. 2. Citações feitas a partir de obra de Nietzsche em alemão têm tradução nossa.

2 Platão declara ter de recorrer ao conteúdo da idéia, para conseguir assegurar o conteúdo de verdadeiro para as coisas. No caso aqui, em que a verdade se funde com a beleza, seu em si é inevitável (Cf. PLATÃO, 1979, p. 106ss.) 